Maurer School of Law: Indiana University

Digital Repository @ Maurer Law

2011

\title{
Morrison, The Effects Test, and the Presumption Against Extraterritoriality: A Reply to Professor Dodge
}

Austen L. Parrish

Indiana University Maurer School of Law, austparr@indiana.edu

Follow this and additional works at: https://www.repository.law.indiana.edu/facpub

Part of the Jurisdiction Commons, and the Transnational Law Commons

\section{Recommended Citation}

Parrish, Austen L., "Morrison, The Effects Test, and the Presumption Against Extraterritoriality: A Reply to Professor Dodge" (2011). Articles by Maurer Faculty. 892.

https://www.repository.law.indiana.edu/facpub/892

This Article is brought to you for free and open access by the Faculty Scholarship at Digital Repository @ Maurer Law. It has been accepted for inclusion in Articles by Maurer Faculty by an authorized administrator of Digital Repository @ Maurer Law. For more information, please contactrvaughan@indiana.edu. 
extraterritorially, and it is worth noting that the Bush administration raised the presumption in Sosa v. Alvarez-Machain and got not a single vote for its argument. ${ }^{31}$

At a more fundamental level, there is an important distinction between the ATS and the antifraud provisions of the Exchange Act: the ATS is simply a jurisdictional provision, whereas Section $10(\mathrm{~b})$ is a rule of substantive law. It is true that the Supreme Court has applied the presumption to the Foreign Sovereign Immunities Act and the Federal Tort Claims Act, ${ }^{32}$ but these acts codify federal rules of sovereign immunity in addition to granting jurisdiction. The ATS, by contrast, is "strictly jurisdictional." 33 This distinction can be found in Morrison itself. Justice Scalia applied the presumption against extraterritoriality to Section 10(b) of the Exchange Act, a substantive provision prohibiting fraud ${ }^{34} \mathrm{He}$ did not apply the presumption to Section $27,{ }^{35}$ the jurisdictional provision for Exchange Act violations, even though it contained no clear indication that it applied extraterritorially at the time. ${ }^{36}$ Rather, Justice Scalia emphasized that the district court did have subject matter jurisdiction under Section $27 .{ }^{37}$ The most plausible reason for the Court's differing treatment of Section 10(b) and Section 27 is that the presumption applies only to substantive statutes and not to jurisdictional ones.

Morrison is the Supreme Court's most important extraterritoriality decision in almost two decades, but understanding it requires care. Morrison shifts the focus of the presumption from the location of the conduct to the location of the effects. This means that RICO should not apply to conduct in the United States that causes effects abroad on or through a foreign enterprise, but should apply to conduct abroad that causes effects in the United States on or through a domestic enterprise. But Morrison does not mean that the presumption applies to jurisdictional statutes like the ATS.

\section{Morrison, the Effects Test, and the Presumption Against Extraterritoriality: A Reply to Professor Dodge}

\section{By Austen L. Parrish*}

Last term, in Morrison v. National Australia Bank Ltd., the U.S. Supreme Court decided what may be the most significant legislative jurisdiction case of the last few decades. In putting an end to so-called "foreign-cubed" securities cases, the Supreme Court strongly reaffirmed the presumption against extraterritoriality. Specifically, the Court held that insufficient evidence existed that Congress intended Section 10(b) of the 1934 Securities and Exchange Act to "provide a cause of action to foreign plaintiffs suing foreign and American defendants for misconduct in connection with securities traded on foreign exchanges."

\footnotetext{
${ }^{31}$ See Brief for the United States as Respondent Supporting Petitioner at 46-50, Sosa v. Alvarez-Machain, 542 U.S. 692 (2004) (No. 03-339), 2004 WL 182581.

${ }^{32}$ See Argentine Republic v. Amerada Hess Shipping Corp., 488 U.S. 428 (1989); Smith v. United States, 507 U.S. 197 (1993).

33542 U.S. 692, 713 (2004); see also id. at 743 (Scalia, J., concurring) (describing ATS as " purely jurisdictional"). If the presumption applies to the ATS, it would presumably apply equally to the federal diversity statute, 28 U.S.C. $\S 1332$, and to the grant of subject matter jurisdiction over "all offenses against the laws of the United States."

18 U.S.C. $\S 3231$. This would be contrary to common practice.

${ }^{34} 15$ U.S.C. $\$ 78 \mathrm{j}(\mathrm{b})$.

${ }^{35} 15$ U.S.C. \$ $78 \mathrm{aa}$.

${ }^{36}$ It has since been amended by $\S 929 \mathrm{P}(\mathrm{b})$ of the Dodd-Frank Wall Street Reform and Consumer Protection Act.

${ }^{37}$ Morrison, 130 S. Ct. at 2877.

"Professor of Law and Vice Dean, Southwestern Law School.

1 Morrison v. National Australia Bank, Ltd., 130 S. Ct. 2869, 2875, 2883, 2888 (2010).
} 
Absent evidence of congressional intent, the Court applied the presumption and found that the law did not apply.

The Court was careful to underscore, however, that the principles articulated in Morrison apply "to all cases," and are not limited to the securities context. ${ }^{2}$ The question then is how to interpret Morrison and its broader implications. To that question, Professor William Dodge has an unexpected and provocative answer. According to him, Morrison not only reaffirms the importance of the presumption against extraterritoriality, but changes the presumption in a fundamental way. For Professor Dodge, Morrison instructs lower courts to focus not on the location of the conduct giving rise to the claim, but on the location of the effects caused by the defendant's conduct. With this reading, Morrison is a case that embraces an effects test approach to legislative jurisdiction. More provocative still, Professor Dodge views this change as "a positive development."

I reach different conclusions. For me, little can be found in the case that would suggest the Court has any fondness for an effects approach to legislative jurisdiction. But even if it did, such an approach would be cause for alarm, not celebration. The extraterritorial assertion of domestic law is problematic, and the effects test exacerbates rather than solves the problems it engenders. More fundamentally, for purposes of the American Society of International Law, an effects-test approach to legislative jurisdiction is in tension with foundational principles of international law. ${ }^{3}$

As an initial matter, one is hard-pressed to believe that the Court intended to embrace an effects approach. The Court expressly repudiated the "effects test"' as a way to "divin[e] what congress would have wanted" regarding a law's extraterritorial reach. ${ }^{4}$ The Court's majority opinion does not mince words in its condemnation. The "effects test," the Court explained, was "judicial-speculation-made law[]" that impermissibly "ignored," " "excised," "discarded," or "disregard[ed] the presumption against extraterritoriality.", The Court also described the test as hopelessly "vague," "not easy to administer," and "unpredictable.", Rather than use the existence of effects as a substitute for congressional intent, the Court clarified that the presumption applies in every case. ${ }^{7}$ Justices Stevens and Ginsburg's concurrence even faulted the majority for repudiating the effects test so thoroughly. ${ }^{8}$

Faced with the stark language of the decision, Professor Dodge focuses on the case's facts to lend support for his position. Because no domestic effects were felt in Morrison, Professor Dodge argues that the result would be different if an effect could be shown. But he reads more into the decision than can be supported. Just because the Court concluded that Congress did not intend to regulate when no effect was felt in the United States, does not mean that courts would find Congress intended to regulate whenever an effect occurs. On the contrary, that some effect is felt in the United States at most is a necessary, but not a sufficient,

\footnotetext{
2 Id. at 2881 .

${ }^{3}$ For more on our competing perspectives, compare William S. Dodge, Understanding the Presumption Against Extraterritoriality, 16 BERKELEY J. INT'L L. 85 (1998), with Austen L. Parrish, The Effects Test: Extraterritoriality's Fifth Business, 61 VAND. L. REv. 1455 (2008). For a general overview, see Jeffrey A. Meyer, Dual lllegality and Geoambiguous Law: A New Rule for Extraterritorial Application of U.S. Law, 95 MINN. L. REv. 110, 114-18 (2010) (reviewing work of Professors Dodge and Parrish).

${ }^{4}$ Morrison, 130 S. Ct. at $2877-81$.

${ }^{5}$ Id.

${ }^{6}$ Id. at $2878-81,2887$.

${ }^{7}$ Id. at 2881.

${ }^{8}$ Id. at 2889-91.
} 
condition to finding regulation. Without an effect, Congress has no power to regulate. ${ }^{9}$ But finding that an effect exists is not a substitute for determining congressional intent. It would be odd indeed if the presumption-intended to prevent exorbitant jurisdictional assertionscould be used to justify almost unlimited extraterritorial jurisdiction. ${ }^{10}$

The disagreement that Professor Dodge and I hold on the reading of Morrison, however, masks a more fundamental difference. For Professor Dodge, extraterritorial laws are, on balance, normatively desirable. I am less optimistic. ${ }^{11}$ Extraterritorial laws are problematic for international law and pose a threat to effective global governance.

First, other countries view an effects approach to legislative jurisdiction with distrust. Extraterritorial regulation is seen as illegitimate and a form of legal imperialism. The effects test particularly has roused widespread foreign resentment. As one commentator colorfully explains, the effects test is perceived as "Yankee "jurisdictional jingoism.",12 This is not surprising. Extraterritorial laws regulating foreigners are inherently undemocratic and impose obligations on individuals and groups who have no formal voice in the political process and who have not consented to those laws. ${ }^{13}$

Second, an effects approach that encourages extraterritorial regulation is at odds with foundational principles of international law. While international law at times permits extraterritorial regulation, it does so hesitantly. ${ }^{14}$ Because of its undemocratic nature, extraterritorial law is in tension with the right to self-governance and self-determination. Extraterritorial laws are also contrary to the premise that the international system should seek to reduce international conflict and tension between states. The post-World War II global system envisioned a world governed by multilateral agreement and stability, not a free-for-all where each state is free to impose its own vision on others, and where exceptionalism, rather than the rule of law, controls.

Third, an effects approach is likely to undermine long-term American interests. When the United States was the only country applying its laws extraterritorially, the effects test was more palatable as a way to build empire and project American influence. ${ }^{15}$ But now that American-style litigation has globalized, other countries have begun experimenting with expanding the geographic reach of their own laws. For weaker nations, extraterritorial laws

\footnotetext{
${ }^{9}$ See Parrish, supra note 3, at 1499 (describing how the effects test defines the outer limits of prescriptive power under international law); see also Lea Brilmayer \& Charles Norchi, Federal Extraterritoriality and the Fifih Amendment Due Process, 105 Harv. L. Rev. 1217, 1223 (1992) (describing constitutional limits on Congress's power to enact extraterritorial legislation).

${ }^{10}$ R.Y. Jennings, Extraterritorial Jurisdiction and the United States Antitrust Laws, 33 BRIT. Y.B. INT'L L. 146 160 (1957) (describing the effects test and explaining that "it would be absurd indeed if an almost unlimited extraterritorial jurisdiction could be ostensibly based upon a territorial principle of jurisdiction"); GARY B. BORN \& Peter B. Rutledge, International Civil Litigation in United States Courts 573 (4th ed. 2007) (questioning whether the "effects doctrine'" provides "almost limitless legislative jurisdiction').

${ }^{11}$ For a more extensive discussion, see Austen L. Parrish, Evading Legislative Jurisdiction, 87 Notre Dame L. REV. (forthcoming 2012); Austen L. Parrish, Reclaiming International Law from Extraterritoriality, 93 MiNN. L. REV. 815 (2009).

${ }^{12}$ John B. Sandage, Forum Non Conveniens and the Extraterritorial Application of United States Antitrust Law, 94 YALE L.J. 1693, 1698 (1985).

${ }^{13}$ See Mark P. Gibney, The Extraterritorial Application of U.S. Law: The Perversion of Democratic Governance, the Reversal of Institutional Roles, and the Imperative of Establishing Normative Principles, 19 B.C. INT'L \& CoMP. L. REv. 297, 312. For an argument that the right to democratic representation is itself an international norm, see Thomas M. Franck, The Emerging Right to Democratic Governance, 86 AM. J. INT'L L. 46 (1992).

${ }^{14}$ See Developments in the Law: Extraterritoriality, 124 HARV. L. REv. 1226, 1229-30 (2011) (describing "international law's powerful norm against extraterritoriality," but noting that "sometimes [the norm] yields to consensual political objectives').

${ }^{15}$ See generally Kal Raustiala, Does the Constitution Follow the Flag? The Evolution of TerritorialITY IN AMERICAN LAW (2009).
} 
become a meaningful way to exert greater influence beyond what they could expect as a result of multilateral negotiation. Americans should be concerned that, following the U.S. lead, other countries will embrace extraterritoriality as a way to impose liability on Americans for conduct occurring in the U.S. and lawful under U.S. law, that is alleged to have an effect abroad.

While these criticisms of the effects approach are significant, Professor Dodge and I share some common ground. Extraterritorial regulation is not always a bad idea. In under-regulated areas, extraterritoriality can sometimes fill a gap. And it may be that extraterritorial regulation can serve as a placeholder before more comprehensive, international agreement can be reached. Certainly, there is no problem with a nation regulating its own citizens and subjects abroad. But Congress should not take the decision to regulate extraterritorially lightly, and, in the face of congressional silence, courts should not simply assume that Congress intended to regulate whenever an effect in the United States exists.

The Morrison case reaffirmed these basic principles. Contrary to Professor Dodge's reading, Morrison correctly interred the effects test and reaffirmed that Congress is presumed to have exercised only its territorial jurisdiction. For those who see the value in primarily resolving global challenges through multilateral agreement, rather than through unilateral domestic action, that is good news indeed.

\section{Morrison v. National australia Bank: Defining the DomestiC INTEREST IN INTERNATIONAL SECURITIES LiTIGATION}

\section{By Hannah L. Buxbaum*}

In Morrison, the U.S. Supreme Court addressed for the first time the extraterritorial reach of Section 10(b) of the Exchange Act. It did so against the backdrop of a jurisprudence developed by the lower federal courts, pursuant to which legislative jurisdiction over crossborder securities claims rested on two alternative bases: conduct occurring within the United States, and effects within the United States of conduct occurring abroad. ${ }^{1}$ Both the District Court for the Southern District of New York and the Second Circuit Court of Appeals had ruled in favor of the defendants, concluding that U.S. law did not apply to the plaintiffs' claims. They did not, however, accept the defendants' invitation to adopt a bright-line rule that conduct could never suffice as a basis for jurisdiction over foreign-cubed claims-that legislative jurisdiction could never be established where the conduct in question had "no effect in the United States or on American investors." 2

The Supreme Court adopted precisely such a bright-line rule-and one that applies not just to foreign-cubed cases, which present particularly serious international comity concerns, but to all types of cross-border securities claims. Rejecting the longstanding conduct and effects tests, the Court adopted in their place a single transaction-based test. Concluding that "the focus of the Exchange Act is not upon the place where the deception originated, but upon purchases and sales of securities in the United States,"3 it held that Section 10(b)

\footnotetext{
- John E. Schiller Chair in Legal Ethics and Executive Associate Dean for Academic Affairs, Indiana University, Maurer School of Law.

${ }^{1}$ This approach is consistent with the jurisdictional analysis used in other substantive areas. See generally Restatement (ThiRd) of the Foreign Relations Law of the United States $\$ \$ 401-403,416$ (1987).

${ }^{2}$ Morrison v. National Australia Bank, Ltd., 547 F.3d 167, 174 (2d Cir. N.Y. 2008).

${ }^{3}$ Morrison v. National Australia Bank, Ltd., 130 S. Ct. 2869, 2884 (2010).
} 